\title{
Prevotella veroralis
}

National Cancer Institute

\section{Source}

National Cancer Institute. Prevotella veroralis. NCI Thesaurus. Code C86679.

A species of obligately anaerobic, Gram-negative, rod shaped bacteria assigned to the phylum Bacteroidetes. This species is nonmotile, non-spore forming, nonpigmented, cellobiose, sucrose, lactose, esculin hydrolysis, beta- $\mathrm{N}$-acetyl-glucosaminidase, and alpha-fucosidase positive, but xylose, arabinose, rhamnose, salicin, indole, and glycine aminopeptidase negative. P. veroralis was isolated from the human oral cavity. 